\title{
Relations of phenometrical indices of apple fruits with weather variation in the assortment of varieties of an apple gene bank
}

\author{
Lakatos, L. ${ }^{1}$, Szabó, T. ${ }^{2}$, Szabó, Z. ${ }^{3}$, Soltész, M. ${ }^{3}$, Sun, Z. $^{4} \&$ Nyéki, J. ${ }^{3}$ \\ ${ }^{1}$ University of Debrecen, Centre of Agricultural and Applied Economic Sciences, Department of Agricultural \\ Engeneering H-4032 Debrecen, Böszörményi 138, Hungary,lakatos@agr.unideb.hu \\ ${ }^{2}$ Fruit Growing Research and Extension Institute H-4244 Úffehértó Vadastag 2.,Hungary \\ ${ }^{3}$ University of Debrecen, Institute of Horticulture, H-4032 Debrecen, Böszörményi 138, Hungary \\ ${ }^{4}$ Inst. of Environment and Development in Agriculture (IEDA), Chinese Academy of Agricultural Sciences (CAAS), \\ No. 12, Zhong-guan-cun South Street Beijing 100081 P.R. China
}

\begin{abstract}
Summary: The purpose of phenometry is to examine the measurable parameters of the plants in order to follow up the consequences of weather processes. We should find the reasons, why the diameter of fruits grows larger in one season and smaller in the next. Variation may occur as a response to insufficient provision of water or nutrients, but also because of pathological effects and of extremely high or low temperatures, moreover, of extraordinary heavy fruit load.

There are phenometrical characteristics, which consider the final consequences (density of flowers, fruits set, drop of fruits), whereas other parameters could be followed up (size, length and width of fruits) as the dynamic components of growth. The quantitative parameters of growth are functionally related to each other, where the weather conditions, soil humidity and nutrients are on the input side, thus it is possible to model the growth of fruits as a function of the environment. Initially, the relations between the main weather variables and the phenometrical data have to be cleared. In the present study, the interactions between the mentioned phenomena are presented and numerically defined.
\end{abstract}

Key words: fruit phenometry, groups of maturity, summer ripening, autumnal ripening, winter ripening, maximum temperature, minimum temperature, precipitation, length of fruits $(\mathrm{mm})$, width of fruits $(\mathrm{mm})$, seed content (number per fruit), trunk circumference $(\mathrm{cm})$.

\section{Survey of the literature}

The phenometry of fruit development has deep roots in Hungary as the first attempts are dated to the 1950-es, when Zerinvári (1950), Berényi \& Justyák (1956) published their study first in orchards and with grapes of hillside vineyards. In 1961, appeared the first study on the climate of vineyards and orchards (Bognár \& Kozma, 1961). The effects of macroand microclimatic happenings on the growth of fruits were first analysed by Szász (1961). A far reaching evaluation of the role of agrometeorology in the Hungarian horticulture is coined with Nyujtó (1965). In the 1960-es, studies appeared analysing the interactions of phenological phasis-lengths and meteorological parameters referring mainly to apple and grape cultures as documented by Csöbönyei \& Stollár (1969). By means of that technique, the security of fruit yields has been improved successfully as well as the performance of fruit varieties revealed. As the particularly hard winters of the period offered the opportunity to develop techniques of saving cultures from frost damage, reports appeared by Pletser \& Radnai (1964). During the 1970-es, a couple of publications dealt with the relations of growth and soluble solids with weather conditions. Studies following up the data raised about evapotranspiration (Füri \& Kozma, 1975), subsequently the consumption of water by apple plantations (Gergely \& Stollár, 1978), and the prediction of the time of maturity by meteorological parameters for the apple variety 'Janathan' was the main stream of research activity (Stollár, 1977). In the 1980-es, the meteorological characterisation of growing sites and its effect on different fruit varieties took place (Stollár \& Zárbok, 1981; Stollár, 1984). The temperature and radiation relations of vegetable stands have been measured (Dunkel et al., 1981), whereas the effects of critical winter temperatures mainly on grape stands followed up (Dunkel \& Kozma 1981; Csapó, 1984).

\section{Material and method}

The plant material was part of a collection of varieties established on the Research Station and Extension Service of the of the Enterprise Fruit Growing Kht. at Újfehértó. Each 
variety was represented by 2 trees in the collection of 586 apple varieties and observed for phonological performance over a period of 1993-2011. The population represented three groups of maturity:

\section{(1) Summer ripening \\ (2) Autumn \\ (3) Winter}

We started observations at the $30^{\text {th }}$ day after bloom until full maturity. 30 days before maturity the observations were started aiming to analyse the effects and interaction of meteorological factors and the phenological happenings. Varieties represented traditional, "old", partly obsolete ones, as well as new and also still promising new varieties. We observed altogether 1172 individual trees. One part of the varieties were planted in 1981 and 1982 trained to spindle crowns grafted on MM106 rootstocks and planted to $8 \times 2$ m density.

Observation s and measurements were concentrated to the growing site Újfehértó. The field was flat at elevation 115 m above sea level, $19 \mathrm{~km}$ south to the town Nyíregyháza. The soil was sandy with a low carbonate humus content, where the reaction was acid ( $\mathrm{pH}$ 5.74-5.79). Total organic components: $<1 \%$.

As for the microclimate the following date were registered: air temperature at one hour intervals, precipitation daily, all being observed automatically on a computer. The following data are used:

1. maximum temperature $\left(\mathrm{T}_{\max }\right)$,

2. minimum temperature $\left(\mathrm{T}_{\min }\right)$,

3. mean temperature $\left(\mathrm{T}_{\text {att }}\right)$,

4. precipitation $\left(\mathrm{Cs}_{\text {össz }}\right)$.

Phenological conditions observed or calculated:

(1) Flower density on a scale 1-5 (estimated)

(2) Fruit density on a scale 1-5 (estimated)

(3) Fruit load (kg)

(4) Fruit fall (June drop) extent (\%) mass of the fruits which fell $(\mathrm{kg})$

(5) Length of fruits ( $\mathrm{mm})$ :

(6) Width of fruits $(\mathrm{mm})$ :

(7) Thickness of fruits ( $\mathrm{mm})$ :

(8) Seed content (number per fruit)

(9) Trunk circumference $(\mathrm{cm})$.

Data have been processed by the Window Excel 97 program. Means and standard deviations are calculated. Phenometrical parameters and meteorological data were processed for linear regression and correlation analysis.

\section{Results}

The size of fruit is influenced significantly by meteorological effects during the growing period. The conditions around the growing site: exposition, soil, climatic and microclimatic moments are individually different also regarding to the phenophase of the same plant. Not only the meteorological elements may differ but also their appearance and distribution of their effect expressed in the parameters and expression of phenometry of fruit development.

The relation of developmental phases and meteorological elements should always regarded as a complex reaction of many factors representing the whole physical environment of the climate, thus effects of a unique factor are always combined with the other moments of the climate. It is not recommended to evaluate the effects of a single meteorological component regardless of the complex background, as most of phenomena are a result of interactions. For example, at low temperatures, the requirement for water is low (the equivalent of water deficiency is low). At high temperatures, all equivalents of precipitation increase substantially, the optimum included because evaporation from the soil as well as from the leaves increase the water requirement, not only the transpiration.

The period between the end of bloom and the start of maturity is considered the time of fruit development. The sum of temperature during this period is in the case of apple varieties ripening during the winter, significantly related to the load of fruits (density of fruits) (Figure 1). As far as the sum of temperature increases from $2500{ }^{\circ} \mathrm{C}$ to $3000{ }^{\circ} \mathrm{C}$ for the period of development, the estimated fruit density changes from 1.9 to 2.7 (taking a scale of $1-5$ ).

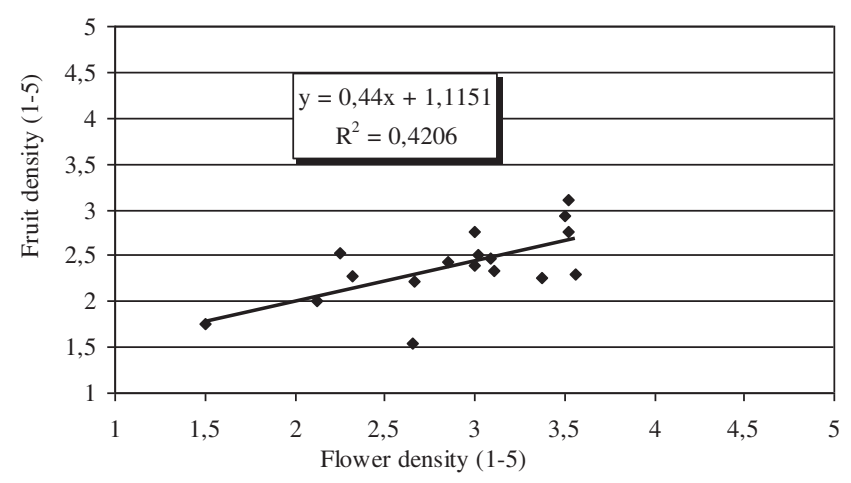

Figure 1 - Relation between the density of fruits set and the sum of temperature during the period from bloom to maturity in winter-ripe apple varieties of the gene bank plantation (Újfehértó, 1993-2011)

As long as in the winter-ripe varieties, the relation is significant on the level of $\mathrm{p}=0.1 \%$ odds, as a linear regression, the summer- and autumn-ripe varieties did not show significant correlation of that type (Table 1).

Table 1. Coefficients of correlation between fruit density and the sum of temperature of the period of development from bloom to maturity in apple varieties of different times of maturity (1993-2011)

Relation between fruit density and the sum of temperature during the period from bloom to maturity in different groups of varieties

\begin{tabular}{|l|c|c|c|}
\hline & Summer-ripe & Autumn-ripe & Winter-ripe \\
\hline $\mathrm{r}$ & -0.14 & 0.31 & 0.68 \\
\hline signific & no & no & $0.1 \%$ \\
\hline
\end{tabular}


Our investigations prove that the size of fruits is most dependent on the minimum temperatures of the period of development (Figure 2).

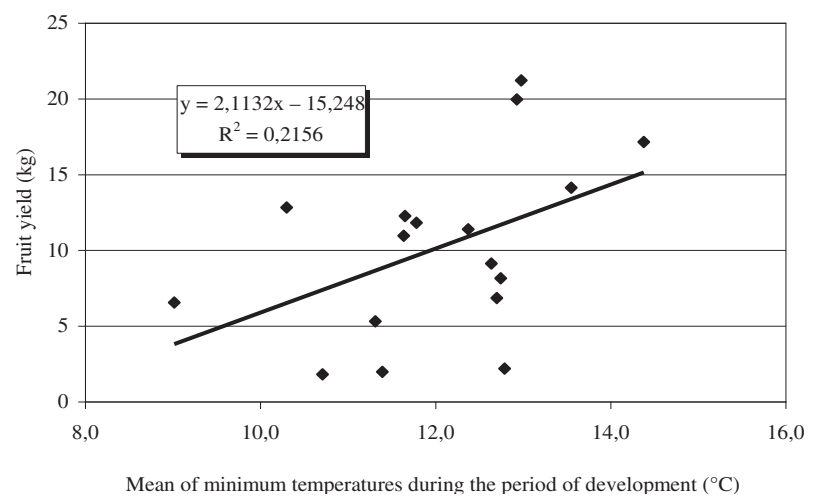

Figure 2 - Relation between the yield of fruits and the mean of daily minimum temperatures during the period from bloom to maturity in summer-ripe apple varieties of the gene bank plantation (Újfehértó, 1993-2011)

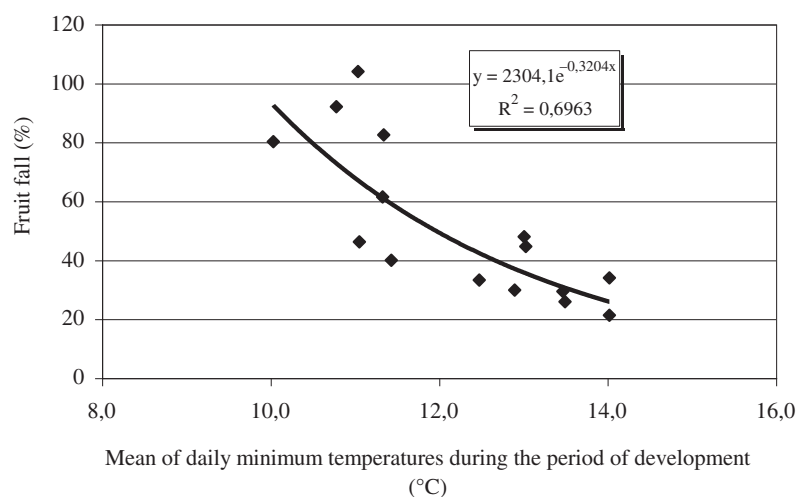

Figure 3 - Relation between fruit fall and the mean of daily temperature minima during the period from bloom to maturity in winter-ripe apple varieties of the gene bank plantation (Újfehértó, 1993-2011)

In summer-ripe varieties the correlation between fruit yield $(\mathrm{kg})$ and mean of daily temperature minima $\left(\mathrm{C}^{\circ}\right)$ of the period of development was significant at $\mathrm{p}=5 \%$ odds. The same relation was not significant in the case of autumn-ripe and winter-ripe varieties either (Table 2).

Table 2. Coefficients of correlation between fruit yield and the sum of mean daily minimum temperatures of the period of development from bloom to maturity in apple varieties of different times of maturity (1993-2011)

Relation between yield and the sum of mean daily minimum temperatures during the period of development

\begin{tabular}{|l|l|l|l|}
\hline & \multicolumn{1}{|c|}{ Summer-ripe } & \multicolumn{1}{|c|}{ Autumn-ripe } & \multicolumn{1}{|c|}{ Winter-ripe } \\
\hline $\mathrm{r}$ & 0.46 & 0.31 & -0.05 \\
\hline signific & $5 \%$ & no & no \\
\hline
\end{tabular}

The increasing of the daily mean temperature minima of the period of development lowered the extent of fruit fall (Figure 3). As far as the mean daily minima were around $10{ }^{\circ} \mathrm{C}, 80-90 \%$ of fruits were dropped, whereas with $14{ }^{\circ} \mathrm{C}$ mean minima, the drop was only around 20-30\%.
In autumn-ripe and winter-ripe varieties, the relation between the drop of fruits and the mean of daily minima was significant on the level of $5 \%$ and $1.0 \%$ of odds. (Table 3 ). In summer-ripe varieties, no significant correlation was found.

Table 3. Coefficients of correlation between fruit fall and the mean minimum temperature of the period of development from bloom to maturity in apple varieties of different times of maturity (1993-2011)

\begin{tabular}{|c|c|c|c|}
\hline \multicolumn{4}{|c|}{$\begin{array}{c}\text { Relation between the extent of fruit fall and the mean minimum } \\
\text { temperatures during the period of development from bloom to } \\
\text { maturity }\end{array}$} \\
\hline & Summer-ripe & Autumn-ripe & Winter-ripe \\
\hline r & -0.09 & -0.48 & -0.84 \\
\hline signific & no & $5 \%$ & $0.1 \%$ \\
\hline
\end{tabular}

Among the phenometrical traits, first the length of fruit has been explored. The sum of daily maximum temperatures determines most the length of fruits. In summer-ripe varieties the relations was proved (Figure 4). The increasing sum of temperature lengthens the form of fruits.

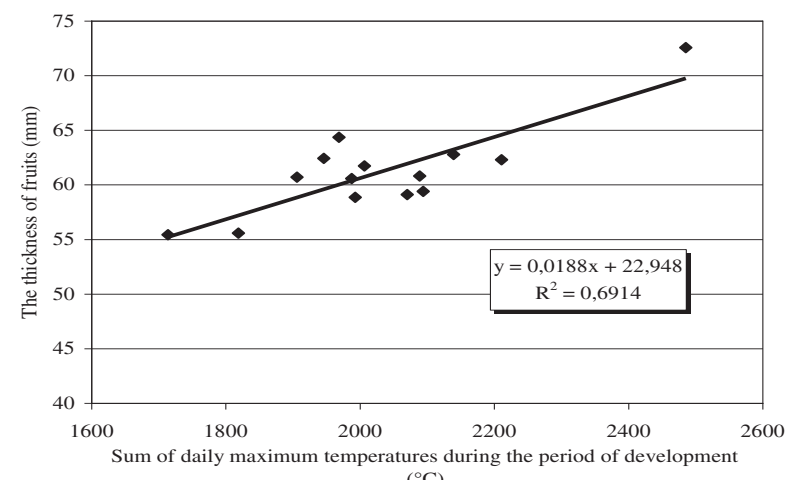

Figure 4 - Relation between the thickness of fruits and the sum of temperature maxima during the period from bloom to maturity in summerripe apple varieties of the gene bank plantation (Újfehértó, 1993-2011)

In summer-ripe apple varieties the correlation is significant at $0.1 \%$ of odds (Table 4 ). In autumn- and winterripe varieties the correlation has not been proved.

Table 4. Coefficients of correlation between the length of fruit and the sum of maximum temperatures during the period of development in groups of apple varieties (1993-2011)

Relation between the length of fruit and the sum daily maximum temperatures during the period of development from bloom to

\begin{tabular}{|l|c|c|c|}
\hline \multicolumn{4}{|c|}{ maturity } \\
\hline $\mathrm{r}$ & Summer-ripe & Autumn-ripe & Winter-ripe \\
\hline signific & 0.75 & 0.06 & -0.07 \\
\hline
\end{tabular}

The width of the fruits was also influenced by the sum of daily temperature maxima. In summer-ripe varieties the correlation was significant (Figure 5). Higher sum of temperature maxima increase the width of fruits. 


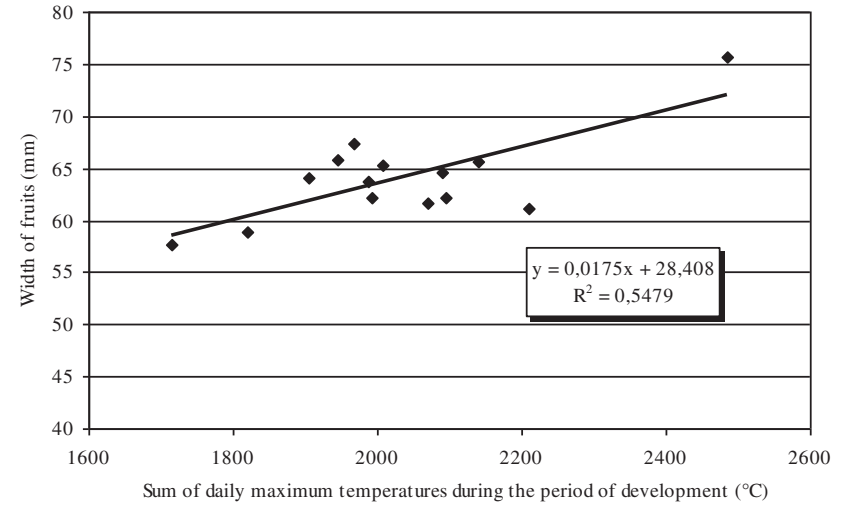

Figure 5 - Relation between the width of fruits and the sum of daily maximum temperatures during the period from bloom to maturity in summer-ripe apple varieties of the gene bank plantation

(Újfehértó, 1993-2011)

In autumn- and winter-ripe apple varieties, on the contrary, there was no significant correlation between the width of fruits and the mean of daily maxima (Table 5).

Table 5. Coefficients of correlation between the width of fruits and the sum of daily maximum temperatures during the period of development in groups of apple varieties (1993-2011)

\begin{tabular}{|l|c|c|c|}
\hline \multicolumn{4}{|c|}{$\begin{array}{c}\text { Relation between the width of fruits and the sum of daily maximum } \\
\text { temperatures during the period of development from bloom to } \\
\text { maturity }\end{array}$} \\
\hline & Summer-ripe & Autumn-ripe & Winter-ripe \\
\hline $\mathrm{r}$ & 0.4 & 0.2 & -0.1 \\
\hline signific & $0.1 \%$ & no & no \\
\hline
\end{tabular}

The thickness of fruits is also influenced significantly by the mean of daily maximum temperatures. It was significant in the summer-ripe varieties on the $\mathrm{p}=0.1 \%$ level (Figure 6 and Table 6). In autumn- and winter-ripe varieties no significance could be found.

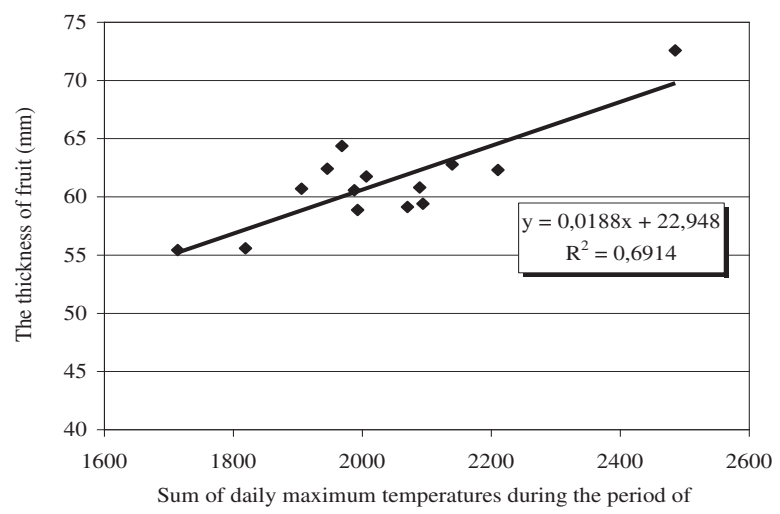

Figure 6 - Relation between the thickness of fruits and the sum of daily maximum temperatures during the period from bloom to maturity in summer-ripe apple varieties of the gene bank plantation (Újfehértó, 1993-2011)

Fruit thickness is dependent on the amount of precipitation of the period before maturity. In autumn-ripe varieties, the sum of precipitation increases the thickness of fruits as raised to a power. In autumn-ripe varieties, it is conspicuous. Small doses have more remarkable effects than additional rainfalls (Figure 7) according to the law of diminishing efficacy.
Table 6. Coefficients of correlation between the thickness of fruits and the sum of daily maximum temperatures during the period of development in groups of apple varieties (1993-2011)

\begin{tabular}{|l|c|c|c|}
\hline \multicolumn{4}{|c|}{$\begin{array}{c}\text { Relation between the thickness of fruits and the sum of daily } \\
\text { maximum temperatures during the period of development from } \\
\text { bloom to maturity }\end{array}$} \\
\hline & Summer-ripe & Autumn-ripe & Winter-ripe \\
\hline $\mathrm{r}$ & 0.83 & 0.11 & -0.06 \\
\hline signific & $0.1 \%$ & no & no \\
\hline
\end{tabular}

In summer- and autumn-ripe varieties, the precipitation during the 30-day-long period before maturity increased decisively the fruit thickness on the level of $\mathrm{p}=0.1 \%$ odds (Table 7). In the winter-ripe varieties no significant influence could be found.

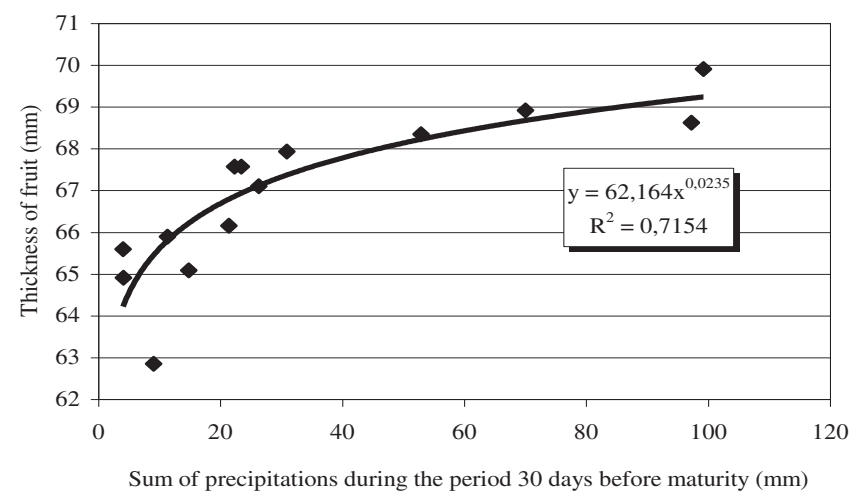

Figure 7 - Relation between the thickness of fruits and the precipitation of the 30-day-long period before maturity in autumn-ripe apple varieties of the gene bank plantation (Újfehértó, 1993-2011)

Table 7. Coefficients of correlation between the thickness of fruits and the precipitation of the 30-day-long period before maturity in different groups of apple varieties (1993-2011)

\begin{tabular}{|l|c|c|c|}
\hline \multicolumn{4}{|c|}{ Relation between fruit thickness and the precipitation of the } \\
30-day-long period before maturity
\end{tabular}

The number of seeds per fruit is a trait of the fruits, which is subject to the mean daily minimum temperatures during the period of fruit development. As shown in Figure 8, the sum of daily minimum temperatures influences positively the number of seeds developed in the fruits of autumn-ripe apple varieties.

In autumn- and winter-ripe varieties, the correlation between the sum of minimum temperatures of the period of development (between bloom and maturity) and number of seeds per fruit was significant with $\mathrm{p}=0.1 \%$ odds (Table 8 ). In summer-ripe varieties, the relation was not significant.

The circumference of trunks was most subject to the sum of means of daily minimum temperatures on the level of $\mathrm{p}=0.1 \%$ odds in winter-ripe varieties (Figure 9). Correlation between the sum of minimum temperatures and trunk circumference was valid in autumn- and of winter-ripe varieties but not in summer-ripe ones. 


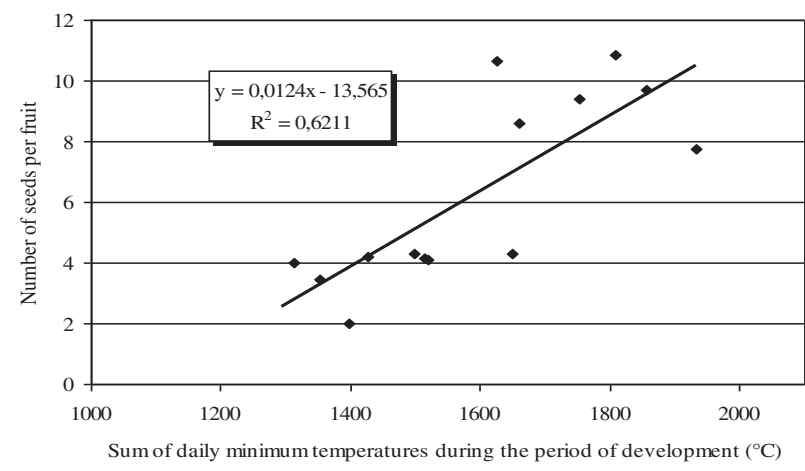

Figure 8 - Relation between the number of seeds and the sum of daily minimum temperatures during the period from bloom to maturity in autumn-ripe apple varieties of the gene bank plantation

(Újfehértó, 1993-2011)

Table 8. Coefficients of correlation between the number of seeds and the sum of daily minimum temperatures during the period of development from bloom to maturity in different groups of apple varieties (1993-2011)

Relation between the number of seeds per fruit and the sum of daily minimum temperatures from bloom to maturity

\begin{tabular}{|l|c|c|c|}
\hline & Summer-ripe & Autumn-ripe & Winter-ripe \\
\hline $\mathrm{r}$ & 0.21 & 0.79 & 0.77 \\
\hline signific & no & $0.1 \%$ & $0.1 \%$ \\
\hline
\end{tabular}

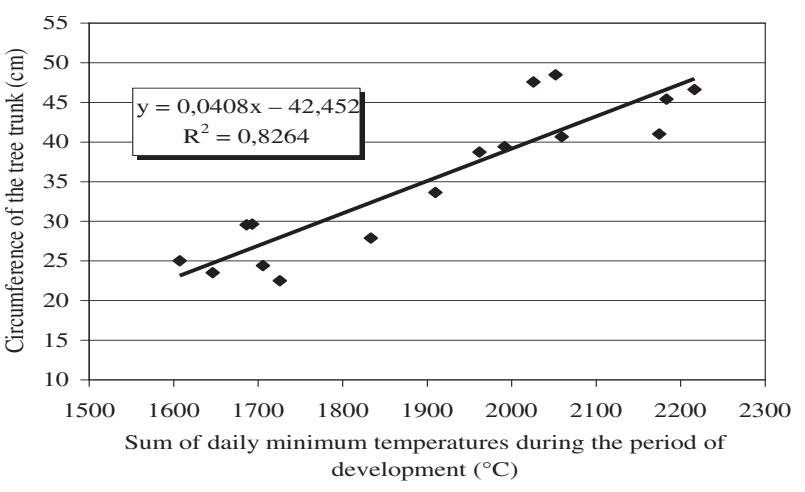

Figure 9 - Relation between the circumference of trunks and the sum of daily minimum temperatures during the period from bloom to maturity in winter-ripe apple varieties of the gene bank plantation

(Újfehértó, 1993-2011)

Table 9. Coefficients of correlation between the circumference of the tree trunk and the sum of daily minimum temperatures in groups of apple varieties of different times of maturity (1993-2011)

Relation between the circumference of tree trunks and the sum of daily minimum temperatures during the period of development

\begin{tabular}{|l|c|c|c|}
\hline & Summer-ripe & Autumn-ripe & Winter-ripe \\
\hline $\mathrm{r}$ & 0.3 & 0.79 & 0.91 \\
\hline signific & no & $0.1 \%$ & $0.1 \%$ \\
\hline
\end{tabular}

\section{Conclusions}

Results presented proved that the dynamics of weather variables exert measurable effects on the development of fruits. Correlations between of phenometric values and meteorological parameters as temperature and precipitation were highly significant in some cases. As a future purpose, we will pay more attention to the time interval between bloom and maturity, where several periods are to be distinguished as being critical from the point of view of developing quantitative as well as qualitative characters of fruits.

\section{Acknowledgement}

This study is funded by TECH_08-A3/2-2008-0373 and TECH_08-A4/2-2008-0138 projects.

\section{References}

Berényi D. \& Justyák J. (1956): Fenológiai felvételezés hegyvidéki szőlőállományban. Időjárás, 2: 104-111.

Bognár K. \& Kozma F. (1961): Együttes szőlő-gyümölcstermesztés mikrometeorológiai vizsgálatáról. Időjárás, 6: 366-369.

Csapó P. (1984): Szőlőültetvények téli fagykárának becslése. Légkör, 1: 19-21.

Csöbönyei I. \& Stollár A. (1969): Az alma rügyfakadása és a rügyfakadás-virágzás fenofázis összefüggése a léghőmérséklettel. Kisérletügyi Közlemények. Kertészet, 1-3: 19-23.

Csöbönyei I. \& Stollár A. (1969): Kapcsolat a Jonathán-alma terméseredménye és az időjárási elemek között. OMSZ. Beszámolók az 1969-ban végzett tud. kut.-ról. 157-161.

Dávid A., Gergely I. \& Stollár A. (1975): A meteorológia elemek hatása a gyümölcs növekedésére és szárazanyag tartalmára. OMSZ. Beszámolók az 1975-ben végzett tud. kut.-ról. 150-157.

Dunkel Z \& Kozma F. (1981): A szőlő téli kritikus hőmérsékleti értékeinek területi eloszlása és gyakorisága Magyarországon. Légkör, 2: 13-15.

Dunkel Z., Kozma F. \& Major Gy. (1981): Szőlőültevényeink hőmérséklet- és sugárzás-ellátottsága a vegetációs időszakban. Időjárás, 4: 226-234.

Füri J. \& Kozma F. (1975): A szőlő tényleges evapotranszspirációja és öntözővíz szükséglete. OMSZ. Beszámolók az 1975-ban végzett tud. kut.-ról. 138-145.

Gergely I. \& Stollár A. (1978): Almaültetvények és tenyészedényben nevelt fák vízfogyasztásának vizsgálata. OMSZ. Beszámolók az 1978-ban végzett tud. kut.-ról. 138-145.

Justyák J. (1985): Szőlőfajták növekedésanalízise Tokajhegyalján. A klímapotenciál és az agrometeorológiai információk népgazdasági hasznosítása. Bp. 337-360.

Nyéki J. (1989): Csonthéjas gyümölcsủek virágzása és termékenyülése. MTA, Budapest, Doktori értekezés (kézirat). 288-110.

Nyujtó F. (1965): Gyümölcstermesztés és agrometeorológia az Alföldön. Kertészet és Szőlészet, 15: 8-9.

Pletser J. \& Radnai K. (1964): Őszibarack fagyvédelme. OMSZ. Beszámolók az 1964-ben végzett tud. kut.-ról. II. rész 135-146.

Schnelle F. (1953): Pflanzenphänologie. Akad. Verlag. Leipzig, 455.

Soltész M. (1992): Virágzásfenológiai adatok és összefüggések hasznosítása az almaültetvények fajtatársításában. MTA Doktori értekezés. 160.

Stollár A. (1977): A gyümölcstermesztés agrometeorológiai vonatkozásai a Duna-Tisza közén. Légkör, 4: 8-10. 
Stollár A. (1977): A meteorológia elemek hatása a jonathán alma érésére. OMSZ. Beszámolók az 1977-ben végzett tud. kut.-ról. 214-219.

Stollár A. \& Zárbok Zs. (1981): A gyümölcsök optimális termőhelyének elemzése hőmérsékleti adottságok alapján. Légkör, 3: 15-17.

Szabó Z. (1997): A kedvezőtlen meteorológiai hatások mérséklése. [In: Soltész, M.: Integrált gyümölcstermesztés.] Mezőgazda Kiadó, Budapest, 353-359.

Szász G. \& Tökei L. (szerk.) (1997): Meteorológia mezőgazdáknak, kertészeknek, erdészeknek. Mezőgazda Kiadó, Budapest, 722.
Szász G. (1961): Makro és mikroklimatikus hatások a köszméte bogyók növekedésére és beltartalmára. Időjárás, 5: 279-288.

Szász G. (1988): Agrometeorológia - általános és speciális. Mezőgazdasági Kiadó, Budapest, 462. p.

Szőke L. \& Kiss E. (1980): Az időjárás hatása néhány szőlőfajta termésének mennyiségére és minőségére. Légkör, 3: 20-22.

Zerinvári E. (1950): Növényfejlődési megfigyeléseink a gyümölcsfákon. Időjárás, 5-6: 154-155. 